\title{
Internationalization and English as a Medium of Instruction in Mongolian Higher Education: A New Concept
}

\author{
Sainbayar Gundsambuu \\ Osaka University; \\ National University of Mongolia
}

\begin{abstract}
Correspondence concerning this article should be addressed to Sainbayar Gundsambuu, Department of Critical Studies in Transformative Education, Graduate School of Human Sciences, Osaka University, 1-1 Yamadaoka, Suita, Osaka 565-0871, Japan. E-mail: sgundsam@fulbrightmail.org
\end{abstract}

\begin{abstract}
The impact of globalization leaves no choice to universities but to go toward internationalization in order to survive in the growing competition in higher education. Following the global trend of internationalization, Mongolian universities plan to increase courses and programs in English in order to improve their competitiveness and ultimately to become internationally visible, at least in Asia. Based on two types of data, documents and an online survey, this study discusses the current process of internationalization at Mongolian universities and explores how faculty members perceive the rationales of implementing English as a Medium of Instruction (EMI). The findings revealed that the Mongolian government is the key player in internationalization through policies, taking initiatives, and encouraging national universities. The faculty members of the two leading private universities in Mongolia perceived that the introduction of EMI at their universities intends to improve their graduates' English language skills to operate globally and as well as to promote their university's international profile.
\end{abstract}

Keywords: internationalization of higher education, English as a medium of instruction, faculty development, international collaboration, joint/dual degree programs

\section{Introduction}

Internationalization of higher education (IoHE) is not a homogenous concept as much as it is a global concept of interrelated dimensions (Hudzik, 2015). IoHE has many aspects, including organized cross-border mobility of students and faculty, foreign language learning, internationalization of curricula, cross-border institutional partnerships in joint research, joint degrees, and branch campuses. There is no agreed-upon definition for IoHE. Soderqvist (2002) provided an early definition of IoHE as "a change process from a national higher education institution to an international higher education institution leading to the inclusion of an international dimension in all aspects of its holistic management in order to enhance the quality of teaching and learning and to achieve the desired competencies" (p.29). However, the most recognized definition is the one put forth by Knight (2003), "Internationalization is the process of integrating an international, intercultural or global dimension into the purpose, functions or delivery of post-secondary education” (p. 2). According to Knight (2004), IoHE has two main spheres of action, "internationalization at home" and "internationalization abroad". 'Internationalization at home' applies strategies and approaches designed to utilize an international dimension into the home campus by including global and comparative perspectives in the curriculum or recruiting international students, scholars, and faculty and leveraging their presence on campus. 'Internationalization abroad' encourages an institution to send students to study abroad, set up a branch campus overseas, or engage in an inter-institutional partnership (Altbach, Reisberg \& Rumbley, 2009).

\section{Rationales for Internationalization}

Rationales for internationalization (Knight \& de Wit, 1997; Knight, 2003, and de Wit, 2000) are categorized into four groups: academic, social/cultural, political, and economic. According to Knight \& de Wit (1997), rationales 
can be described as motivations for internationalization and different rationales imply different means and ends (de Wit, 2000). These rationales have become the most widely recognized set of motivations for the IoHE. In addition to the four categories, Knight (2004) added a new category, branding and developing an international reputation, particularly through rankings.

To clarify the categories of the five rationales, Knight (2004) divided them between the national and institutional levels. At the national level, rationales that drive internationalization in higher education include human resource development, strategic alliances, commercial trade, nation building, and social/structural development; while institutional-level rationales cover international profile and reputation, student and staff development, income generation, strategic alliances, and research and knowledge production (see Knight, 2004).

For this study, it is important to understand the rationales for internationalization, as one of the reasons and motivations includes the implementation of EMI. Thus, this study will examine the rationales for implementing EMI from the perspectives of staff and faculty members at private universities through an online survey to determine the rationales and policies for adoption of EMI at the institutional level in Mongolian higher education context.

\section{English as a Medium of Instruction}

IoHE has become a priority for education systems in many countries where English is not the national language. This is closely connected to the use of English (Yonezawa \& Shimmi, 2015). One of the reasons for this is that as a lingua franca, the use of English represents how non-Anglophone countries try to enter the competitive arena of global higher education and the economic marketplace (Stigger, 2018, p.4). As Coleman (2006) claimed, the reasons for the HEIs to introduce programs and courses taught through EMI are split into seven categories: content and language integrated learning, internationalization, student exchanges, teaching and research materials, staff mobility, graduate employability, and the market in international students. In other words, foreign language learning in itself is not the reason why institutions adopt English medium teaching.

EMI is one trend in IoHE across many non-English speaking countries as countries shift their focus from teaching English to teaching academic subjects in English (Graddol, 1997; Dearden, 2015). EMI is defined as, "The use of the English language to teach academic subjects in countries or jurisdictions where the first language of the majority of the population is not English" (Dearden, 2015, p.2). EMI is a growing global phenomenon in all phases of education, and more and more universities are in a rush to offer both graduate and undergraduate programs through EMI (Macaro et al., 2018). By offering courses in English, an institution is able to attract international students and faculty members, and this brings opportunities for its own students and teachers to participate in international scientific research (Graddol, 1997).

\section{Literature Review}

The literature review explores the process of IoHE at both national and institutional levels and the concept of EMI in Mongolia. In order to view the process and concept, it is important to understand the higher education system of the country, in this case, Mongolia. This is followed by the background on national and institutional policies for internationalization and adoption of EMI.

\section{Higher Education System in Mongolia}

Mongolia is a landlocked country with 1.5 million square kilometers of land area, a total population of 3.1 million and a gross domestic product per capita of $\$ 7,800$ as of $2016 .{ }^{1}$ The total number of students in tertiary education amounted to 155,248 (58\% female) as of 2017. In the same year, 95 HEIs including a high percentage of private institutions (78\%), national (18\%), and a small percentage of branch schools of foreign universities (4\%) are operating in Mongolia. ${ }^{2}$ The branch schools of foreign universities include three from the Russian Federation and one from Singapore.

\footnotetext{
1 Mongolian Statistical Information Service. (2016). Statistical Yearbook 2016. Retrieved from http://www.en.nso.mn/index.php

2 Ministry of Education, Culture, Sciences, and Sports. (2017a). Higher Education Statistics 2016-2017. Retrieved from http://www.mecss. gov.mn/data/1702/HSta1617st
} 
The history of Mongolian higher education is rooted in the National University of Mongolia, which was established in 1942 with three faculties: medical, pedagogical, and veterinary (Gantsog \& Altantsetseg, 2003). Since then, several faculties were developed: physics, mathematics, natural sciences, social sciences, economics, law, and languages and literature. After Mongolia transferred to a free market economy system from a command economy in the 1990s, the government ceased most of its funding for national universities, only covering utility costs. This resulted in the introduction of a student fee structure in 1993 (Gantsog \& Altantsetseg, 2003). Moreover, the government of Mongolia made a policy of 'cost sharing' to shift a greater portion of the burden of payment to individuals and transferred public expenditure on education to student loans. The government also legalized the establishment of private universities and branch schools of foreign HEIs.

\section{Internationalization of Higher Education}

Despite a handful of studies that discussed the early internationalization initiatives in Mongolia, little is known of current strategies and activities towards internationalization at national and institutional levels. Previous studies focused on the impact of globalization on higher education (Gantsog \& Altantsetseg, 2003; Sodnomtseren, 2006), educational expansion in higher education (Agvaantseren \& Hoon, 2013), or a strategy for internationalization in one national institution (Jargalsaikhan, 2015).

At the national level, the Mongolian Sustainable Development Vision-2030, enacted by the Mongolian Parliament in 2016, set an ambitious goal to have at least four Mongolian national universities recognized internationally for research in STEM fields. It indicated,

Build a science and technology cluster and park in accordance with priority development areas, and ensure that no less than four Mongolian universities are ranked among Asian top universities. ${ }^{3}$

There is no data for Mongolian HEIs in the popular ranking systems, such as Times Higher Education's World University Rankings, Academic Ranking of World Universities, and QS World University Rankings. However, the Ministry of Education, Culture, Science, and Sports is cooperating with the QS ranking system to rank Mongolian universities starting from $2020 .^{4}$

In order to become internationally recognized through these rankings, Mongolian national universities will need to focus more on research and publication as it is one of the key indicators. The proportion of online scientific papers from Mongolia reached 315 in 2016 but dropped to 252 in 2017 (Hu, 2017). This shows that the number of papers produced per year remains low. To increase it, two measures are urgent. The government needs to increase the budget for research and development whereas national universities should offer more reward to prominent faculties and researchers.

Mongolian HEIs are also changing their fundamental missions, hoping to become international universities. According to Altbach, Reisberg, \& Rumbley (2009), at the institutional level, a large number of universities around the world aim to produce 'global citizens' with 'global competencies' by adopting extended missions under internationalization. Mission statements of a number of Mongolian HEIs highlighted that they aim to become "global", i.e. an internationally recognized university. Table 1 compares excerpts of mission statements from several major national and private HEIs that aim to become research-oriented and leading institutions in Asia and the world.

Mission statements show that becoming recognized in the region, improving research, technology, and innovation, and integrating into international standards are the main goals set by these universities.

Within the initiatives and policies of IoHE, the government of Mongolia in cooperation with its national universities, aims to develop a comprehensive university campus outside the capital city, Ulaanbaatar. ${ }^{5}$ The

\footnotetext{
3 Partnership for Action on Green Economy. (2017). Mongolia Sustainable Development Vision 2030, 28. Retrieved from http://www.un-page. org/files/public/20160205_mongolia_sdv_2030.pdf

4 Ministry of Education, Culture, Sciences, and Sports. (2019). Minister of MECSS meets national universities' heads. Retrieved from https:// mecss.gov.mn/news/1344/

5 Government of Mongolia. (2010a). Resolution on Ratification of Developing Universities with Building Campuses. Retrieved from http://www. mecss.gov.mn/director-content-312-317.mw
} 
Table 1

Comparison of HEIs mission statements

\begin{tabular}{|c|c|c|c|}
\hline & Type & Name & Excerpt from Mission Statements \\
\hline 1 & National & National University of Mongolia & $\begin{array}{l}\text { “...to become a national model research university which meets } \\
\text { world standards" and provides pillars for Mongolia's development." }\end{array}$ \\
\hline 2 & National & National University of Medical Sciences & $\begin{array}{l}\text { "...to become a national leading and one of the top } 100 \text { medical } \\
\text { universities* in the west coastal area of the Pacific Ocean." }\end{array}$ \\
\hline 3 & National & National University of Life Sciences & “...to become a leading global university*...” \\
\hline 4 & National & Mongolian University of Science and Technology & “...to become one of Asia's top universities*” \\
\hline 5 & National & National University of Education & $\begin{array}{l}\text { “...to become a competitive institution* among Asian universities of } \\
\text { education." }\end{array}$ \\
\hline 6 & Private & Ikh Zasag International University & “...be a modern global university* of technology and innovation.” \\
\hline 7 & Private & University of the Humanities & “...to become a reputable and leading university in Asia*...” \\
\hline 8 & Private & University of Finance and Economics & $\begin{array}{l}\text { "...to become a leading research university* recognized in the } \\
\text { region..." }\end{array}$ \\
\hline 9 & Private & Otgontenger University & $\begin{array}{l}\text { “...to become a research university that satisfies international } \\
\text { standards...” }\end{array}$ \\
\hline 10 & Private & Mongolia International University & $\begin{array}{l}\text { “...to educate and develop leaders in Mongolia and throughout } \\
\text { Central Asia }{ }^{*} . . ”\end{array}$ \\
\hline 11 & Private & Mongolian Royal Academy & “...to be a university that provides world-class education*...” \\
\hline 12 & Private & Mongolian National University & $\begin{array}{l}\text { “...to become a university that leads in Mongolia, Asia, and Europe } \\
\text { through research and teaching*." }\end{array}$ \\
\hline
\end{tabular}

Note: Data are from websites of each institution (translated by the author)

* Italics are inserted by the author

goal of the policy is to integrate international dimensions into the national educational system and support the transformation of national and private universities to a campus model. The government of Mongolia believes that building up a comprehensive campus will lay a solid infrastructure for adapting the national universities' strategic development goals and improving teaching and research quality. The comprehensive campus development plan will also allow the integration of educational resources among the national universities. In addition, national universities will be able to share resources, develop interdisciplinary research, and pursue a coordinated external relations strategy.

With the goal to improve the quality of higher education through internationalization, the government merged national universities reducing the number from 42 to 16 in $2010 .{ }^{6}$ The private HEIs also started to merge voluntarily following the government policy. The number of private institutions which amounted to 129 in 2004 reduced to 79 in 2014 and subsequently to 74 in 2017. In addition, external assessment and accreditation have become necessary to improve the quality and status of higher education in Mongolia. Currently, 74 universities qualified for national accreditation. ${ }^{7}$ The accreditation of HEIs was on a voluntary basis until 2016 when the government made it mandatory for all types of HEIs to undergo accreditation. ${ }^{8}$

\section{English as a Medium of Instruction in Mongolia}

Based on the document analysis, this section outlines the background of English language education and then discusses the current situation of EMI in the country. The Mongolian education system policies aimed to teach only Russian as a foreign language when the country had close ties with the former Soviet Union. During the socialist period, it was mandatory for all students regardless of their fields to learn Russian for 3-4 years continuously and take a state examination in Russian. This was changed when the English language department opened at the National University of Mongolia in 1956. In the 1990s, when Mongolia expanded its

\footnotetext{
6 Government of Mongolia. (2010b). Resolution on Reforming of Some State Owned Higher Education. Institutions. Retrieved from http://www. mecss.gov.mn/director-content-313-317.mw

7 Mongolian National Council for Education Accreditation. (2017). Accredited institutions. Retrieved from http//accmon.mn/accreditedinstitutions-final/

8 Legal Info System. (2017). Approval of Program. Retrieved from http://www.legalinfo.mn/law/details/4992?lawid=4992
} 
foreign relations with other countries, it needed more professionals with English language abilities. Although more HEIs started to offer English courses, there were not enough English language teachers. In 1990-1995, with the support from United Nations Development Program and Overseas Development AdministrationBritish Overseas Development Agency, a specialized English language institute was founded to retrain hundreds of Russian language teachers as English language teachers (Altan-Od \& Khongorzul, 2012).

English is not the second official foreign language in Mongolia. However, the documents on the English language in the past two decades show that English is treated as the second main foreign language in Mongolia. In 1997, the Minister of Enlightenment passed an order to teach English as a foreign language from the academic year of 1997-1998 in all levels of educational institutions. ${ }^{9}$ Later, the order by the Ministry of Education, Culture, and Sciences indicated that the main foreign language in bachelor's level programs would be English. ${ }^{10}$

The term, EMI, was first used officially in the Comprehensive National Development Strategy of Mongolia, which was based on the Millennium Development Goals. ${ }^{11}$ The strategic objective 2 in Education Development Policy indicates the government will, “...provide financial support to high schools, vocational schools, and universities which use English as the medium of instruction" (World Bank, 2008, p.19). Moreover, this document addressed the importance of English, pointed out the goal of making the English language a major foreign language in Mongolia, and set a goal to prepare civil servants with English competencies by 2021. Prior to this official document, in its resolution on English language education, the government of Mongolia (2001) announced the need to teach EMI courses in fields such as international relations, economics, journalism, tourism, medicine, and technology. The National Program on English Education highlighted the importance of "creat[ing] a system/ mechanism pushing the need and use of English as the main tool for education, for communication, information access, and business... ${ }^{12 "}$

Currently, national and private universities in Mongolia offer, in total, around 385 EMI courses (see the document analysis section). However, despite a handful of private universities, opportunities to earn academic degrees in English are limited. Examples include the Mongolia International University that has been offering undergraduate degree programs entirely in English since its establishment in 2002. Another institution is the Royal International University, which opened its doors offering business degree programs entirely in English in 2010. At the graduate level, opportunities to gain degrees in English are available in joint and dual degree programs (mostly Master's degree) at major national and private universities.

This study explores the factors driving Mongolian higher education to pursue internationalization and EMI based on the literature review. The study attempts to answer the following two research questions:

1. What are the driving factors of Mongolian higher education to pursue internationalization and English Medium Instruction?

2. How do the faculty members understand these rationales?

\section{Materials and Methods}

The study consists of an analysis of two main sets of data: 1) documents and 2) an online survey. The following section explains the data collection and analysis. All data related to Mongolian higher education, reforms, internationalization policy, and English language policy went through a qualitative document analysis, "describing, classifying and connecting" (Coffey and Atkinson, 1996, p.8) to portray a comprehensive picture of the IoHE and the concept of EMI in Mongolia.

\footnotetext{
9 Ministry of Enlightenment. (1997). Resolution \# 208 on Some Measures for Foreign Language Training. Retrieved from http://www.mecss.gov. $\mathrm{mn} /$

${ }^{10}$ Ministry of Education, Culture, and Sciences. (2006). Resolution \# 481 on making an amendment in the standard module. Retrieved from http://www.mecss.gov.mn/

${ }^{11}$ World Bank. (2008). The Millennium Development Goals-based Comprehensive National Development Strategy of Mongolia. Retrieved from http://siteresources.worldbank.org/INTMONGOLIA/Resources/NDS_DRAFT_ENG.pdf

${ }^{12}$ Government of Mongolia. (2008). Resolution on Ratification of the National Program on English Language Education, 5. Retrieved from http://www. mecss.gov.mn/director-content-331-317.mw
} 


\section{Document analysis}

Following qualitative document analysis methods (Coffey and Atkinson, 1996), an array of documents was collected from general and academic sources. The collected documents included: policy documents related to Mongolian higher education since the 1990s, government orders, amendments, higher education legislation; websites of 10 national universities and 18 private institutions (as of 2017); official reports by the World Bank, Asian Development Bank (ADB), and Open Society Institute; selected online newspaper articles at three main newspapers (Daily News, Unuudur, and Zuunii Medee); and previously published articles written in both Mongolian and English. Most documents were available in Mongolian; thus, the researcher, as a native Mongolian speaker, had the advantage to analyze the documents in their original language. In addition, the researcher used his insider perspectives working in the higher education sector in Mongolia in the last 14 years. However, it should be noted that the collected documents lacked recent empirical studies and articles related to the topic in this study.

First, the collected documents were read closely to find topic codes which described the main segments of the documents. During the qualitative document analysis, the emphasis was given to official evidence relating to the strategies and approaches for internationalization and EMI policy at the national level. After completing the initial coding process, the coded data were reviewed again and coded segments that reflected similar concepts were grouped into larger categories. After all coded data had been categorized, the categories were reexamined to identify major themes in a relationship with the IoHE in the Mongolian context and the questions of the study. As a result, six dimensions were identified, four of which are presented in this report due to their larger scale.

In addition, documents from 28 national and private universities were collected to understand their EMI policies and the implication of EMI in their strategic plans, mission statements, and public identity. It should be noted that there is no available data on EMI in Mongolia. The number of courses (385) in English was discovered by the author through his private contacts with the 28 universities' academic affairs offices. However, it was not possible to identify the exact number of degree programs and courses in English in the Mongolian HEIs. The reasons include unresponsiveness when reaching out to the universities' academic affairs offices and inaccessibility of information from the university websites.

\section{Online survey}

Based on documentary evidence, an online survey was conducted with faculty members who teach EMI courses at two leading private universities in Mongolia. The survey was developed based on the objectives and the related literature. To ensure that the questionnaire was free from error, its content was subjected to pretesting in two ways. First, I asked experts in research in higher education to comment on the questionnaire focusing on clarity, question-wording, validity and order of the questions. Second, I piloted the questionnaire with ten faculty members at the National University of Mongolia. Feedback from education experts and the pilot study was used to make corrections on the questionnaire.

The survey was conducted at the two universities in Ulaanbaatar, the capital of Mongolia. Purposive sampling (Patton, 2002) was used to select these universities. As Patton (1990) emphasized, purposeful sampling lies in selecting information-rich cases for in depth study. From the information-rich cases, one can learn a great deal about issues of central importance to the purpose of the research. From the 17 strategies for purposefully selecting information-rich cases by Patton (1990), the third strategy, Maximum Variation sampling, was used to select the two universities for the survey. This strategy aims at capturing and describing the central theme or principal outcomes that cut across a great deal of participants or program variation. In addition, document analysis revealed that these two universities have more EMI degree programs than other private universities. National universities were excluded due to a limited number of programs taught in English despite their joint and dual degree programs. At the time of the survey, National University of Mongolia had only one joint business degree program in English while Mongolian National University of Medical Sciences, Mongolian University of Life Sciences, and Mongolian National University of Education had no active degree programs in English (personal communications).

The survey explored faculty members' understandings of the rationales for EMI and examined its implementation 
in two private universities. To provide rich data about the implementation of EMI, the survey targeted two private universities that have adopted an EMI earlier and have implemented it most aggressively among Mongolian HEIs. The survey was originally distributed to 25 faculty members in University A and 30 faculty members in University B. Twenty faculty members from each university who are teaching EMI courses participated in the survey (see Table 2). Most of the faculty members were identified through the email contact with the program deans and some were recruited via direct private email. To ensure that respondents in the survey provided sincere answers, the survey was conducted anonymously and it did not request names and other private information that may reveal their identities.

Table 2

Demographic characteristics of the respondents $(n=40)$

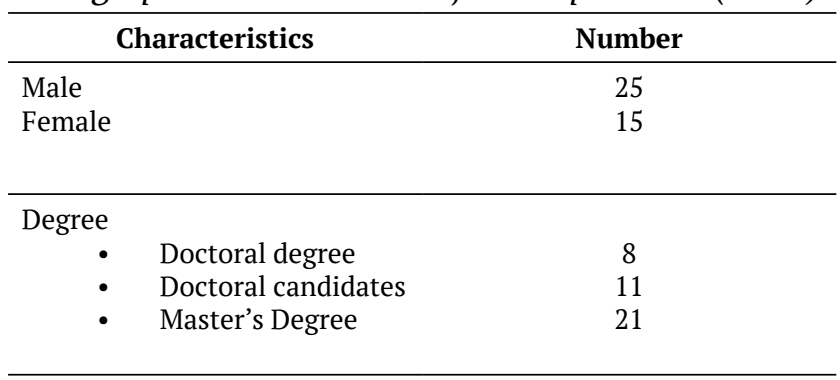

Teaching experiences by year

- 3 or less 12

- 4 or more 6

- 5 or more 6

- 10 or more 16

The survey had 18 questions: five questions on respondents' personal information such as history/experience of teaching courses in English, the experience of teaching overseas, seven yes-no and multiple-choice questions, four five-level Likert-scale and two open-ended questions (see Attachment $\mathrm{A}$ ). The online questionnaires that were designed in English in the Google forms sent to the faculty members in January 2018. The questionnaire was closed in February 2018. The majority of the respondents' nationality was Mongolian (24 faculty members) while the rest were American (5), Bangladeshi (2), Korean (7), and Chinese (2).

\section{Results}

\section{Document analysis: Main dimensions of internationalization}

The document analysis identified six main dimensions of the internationalization process in Mongolian higher education: (1) Administrative leadership and structure; (2) Faculty development; (3) Internationalized curriculum development; (4) Student mobility; (5) Distance Education' and (6) International partnership and collaboration. This section explores the four dimensions $(2,3,4$, and 6$)$ in the internationalization processes of Mongolian HEIs in global and local contexts, their actions and strategies, and underlying motivations.

\section{Faculty development}

The role of faculty members is vital in the institutional internationalization process. Hiring new faculty members or developing existing faculty members is central to the success of approaches to internationalization and maintenance of quality standards. The Mongolian government action plan of 2008-2012 indicated in the section under education, “...faculty development program will be implemented in HEIs", and “...Young researchers and scholars will be supported" in order to improve higher education quality and standards." ${ }^{13}$ In addition, the Roadmap for Higher Education Reform sets goals for faculty development for 2010-2021 to increase the number of higher education faculty members with a PhD by at least 50 per cent. ${ }^{14}$ Currently, 2034 of 6917 (29\%) full-time

\footnotetext{
${ }^{13}$ Legal Info System.(2018).Mongolian Government Action Plan 2008-2012. Retrieved fromhttp://www.legalinfo.mn/annex/details/3295?lawid=6187

${ }^{14}$ Ministry of Education, Culture, Sciences, and Sports. (2017b). Roadmap for Higher Education Reform 2010-2021. Retrieved from http://www. mecss.gov.mn/roadmap201021
} 
faculty members have a PhD. ${ }^{15}$

Since the 1990s, faculties in HEIs have had scarce opportunities and resources to develop their skills and knowledge. Although international philanthropic organizations such as the Open Society Institute offered short-term exchange programs for faculties across all HEIs, faculties still lacked language skills to benefit from international training. However, this is changing and national universities are now focusing more on faculty development in order to increase their quality and visibility.

According to the categories of faculty development developed by Fink (2013), Mongolia belongs to the first level of faculty development, "little or no faculty development activity". Main national universities are striving to offer more faculty development opportunities, thus, aiming for the second level, "a substantial minority of institutions offering faculty development activity where participation is voluntary".

Despite these initiatives, the majority of HEIs still do not have a comprehensive plan for faculty development and faculty members spend little time for self-development due to a heavy workload (Narankhuu \& Batkhishig, 2015). Most of the faculty members (67\%) at national universities viewed developing academic research and foreign language skills as the top priority in faculty development (Itgel., et al, 2018). This means that faculty members feel disadvantaged in participating in and conducting high-quality academic research in a foreign language, mainly in English.

\section{Internationalization of curriculum}

At the national level, in the Roadmap 2021, the government of Mongolia (2010c) set out two important goals: to intensify the work to involve professional and technical schools' programs in an international accreditation in the strategic goal 2.2; and strategic goal 4 to bring closer the graduate degree programs to international standards. In regard to the curriculum development, currently, the Ministry of Education approves all curricula and their corresponding plans. ${ }^{16}$ The National Council for Education Accreditation (NCEA), an independent external government agency, accredits HEIs and academic programs. As of 2015, the NCEA accredited 203 higher education programs. ${ }^{17}$

As indicated in the Roadmap 2021, the NCEA implemented the Higher Education Reform Project in 20122018 in cooperation with the ADB. One of the goals of this project aimed to develop a national program and curriculum with an expected outcome of improved quality and enhanced higher education programs. ${ }^{18}$ As a result, an accreditation agency for study programs, ASIIN e.V from Germany, was selected to develop Twinning Project in Mongolia. Through this project, Mongolia hopes to strengthen the NCEA's accreditation system and improve the quality assurance of programs in higher education.

There is another project by the NCEA, in cooperation with the European Union's ERASMUS+ Project, called, "Promoting internationalization of research through establishment and operationalization of cycle 3 quality assurance system in line with the integration" (C3QA). The project aims to contribute to the establishment of a knowledge-based society in partner countries through the launch and operationalization of a robust quality assurance system for internationalization of Cycle 3 programs. ${ }^{19}$ Currently, the project is in progress at two universities in Mongolia by focusing on updating the current national policy framework for doctoral level degree programs in line with the European integration agenda and establishing an external and internal quality assurance system.

It seems that internationalized curriculum also means an external accreditation by an international accreditation body (see Table 3). Accordingly, Mongolian HEIs seek external accreditations from international accreditation institutions such as Accreditation Council for Business Schools and Programs (ACBSP), Association for Medical

\footnotetext{
15 Ministry of Education, Culture, Sciences, and Sports, 2017a.

${ }^{16}$ Ministry of Education and Sciences. (2016). Education quality reform policy 2012-2016. Retrieved from https://mecss.gov.mn/media/ uploads/72c3d1c8-28a2-492c-979b-5b3c53d179d7.pdf

17 National Council for Education Accreditation. (2019a).Accredited higher education programs. Retrieved from http://accmon.mn/accredited-programs/

${ }^{18}$ National Council for Education Accreditation. (2018). ADB's Higher education reform project. Retrieved from http://accmon.mn/highereducation-reform-project-of-adb/

${ }^{19}$ C3QA. (2019). Promoting internationalization of research through establishment and operationalization of Cycle 3 Quality Assurance System in line with the European Integration Agenda / C3QA.
} 
Education in the Western Pacific Region (AMEWPR), and Accreditation Agency for Degree Programs in Engineering, Informatics, the Natural Sciences and Mathematics (ASIIN).

Table 3

Internationally accredited institutions

\begin{tabular}{llc}
\hline \multicolumn{1}{c}{ International Accreditation } & \multicolumn{1}{c}{ University } & Year of Accreditation \\
\hline ACBSP & University of Finance and Economics & 2012 \\
& Business School, National University of Mongolia & 2013 \\
& School of Business Administration and Humanities & 2013 \\
& Mandakh Burgtel Institute & 2014 \\
& San Institute & 2014 \\
& Etugen University & 2014 \\
& Business School, University of Life Sciences & 2014 \\
& Ide Institute & 2014 \\
& National University of Economics & 2017 \\
& Otgontenger University & 2017 \\
& Business School, University of the Humanities & 2017 \\
& Institute of International Economics and Business & 2017 \\
\hline AMEWPR & Medical School, Mongolian National University of Medical Sciences & 2012 \\
\hline ASIIN & School of Energy, Mongolian University of Science and Technology & 2015 \\
& Mongolian National University of Medical Sciences & 2016 \\
& Mongolian University of Science and Technology & 2016 \\
\hline
\end{tabular}

Note: Data are from National Council for Education Accreditation ${ }^{20}$

Domestically, the government encourages national universities to update their curricula with contents that address international issues and provide intercultural communication skills. With regard to international standards, the government passed an order to follow the United Nations Educational, Scientific and Cultural Organization's International Standard Classification of Education. Accordingly, 817 fields of studies were reduced to 181 in $2014 .{ }^{21}$ The development of joint/dual degree programs in a foreign language (mostly in English) also accelerates the internationalization of curriculum in higher education.

\section{Student mobility}

Mongolia hosted 1,520 inbound international students in $2017 .{ }^{22}$ Of these, $56 \%$ were studying at the bachelor's level, $33 \%$ at the master's level and $11 \%$ at the $\mathrm{PhD}$ level. The geographical origin of incoming students reveals that the largest number of students are from China (969), Russia (182), and South Korea (132), representing 84\% of all international students. Compared to the last five years, the number of international students increased by $0.7 \%$ (from 1,098 in 2012) ${ }^{23}$ In addition, the "EBI" government-funded short-term scholarship (initiated by the former President Elbegdorj in 2017) encourages inbound student mobility. The purpose of the program is to support foreign young researchers and scholars conducting research in Mongolian studies. Currently, nine researchers from eight countries received this scholarship in 2017. ${ }^{24}$

As Enkhtur (2019) outlined, as of 2017, 17,674 Mongolian students ${ }^{25}$ are estimated to be studying abroad at tertiary leve ${ }^{26}$ which is a large number when compared to the total domestic gross enrollment rate of 155,248

\footnotetext{
${ }^{20}$ National Council for Education Accreditation. (2019b). International accreditation. Retrieved from http://accmon.mn/internationalaccreditation/

${ }^{21}$ Ministry of Education and Sciences. (2014). On approval of indexes for fields of education in undergraduate degree level. Retrieved from https://mecss.gov.mn/law/200/

${ }^{22}$ Ministry of Education, Culture, Sciences, and Sports, 2017a

${ }^{23}$ Ministry of Education, Culture, Sciences, and Sports, 2017a

${ }^{24}$ Ministry of Foreign Affairs. (2017). “EBI” Scholarship for Foreign Young Mongolists. Retrieved from http://www.mfa.gov.mn/?p=40643

${ }^{25}$ CSIS-China power. (2018). Is China both a source and hub for international students? Retrieved from https://chinapower.csis.org/chinainternational-students/?fbclid=IwAR1TjGNTK17xKuzU1hveSW9vYGDJFUbOeyQVEW6rCj8qiGY06pVuaD1XMJE

${ }^{26}$ UNESCO Institute for Statistics. (2018). Outbound mobility ratio [online]. Available from: www.uis.unesco.org/education/Pages/international-
} 
in 2017. ${ }^{27}$ The lack of a quality higher education system has been one of the reasons for the outbound mobility of Mongolian students (Loo, 2017). During the Cold War period, the majority of Mongolian outbound students went to the Soviet Union and other communist countries, such as East Germany. As Mongolia was one of the closest satellite countries of the Soviet Union, the leaders and top professionals were prepared in the Soviet Union. The host countries diversified in the last two decades and in 2017 the top destination countries with most Mongolian students were China, South Korea, Japan, Russia, and the United States (see Table 4).

Table 4

Top destination countries of Mongolian outbound students (total outbound students 17,674)

\begin{tabular}{lcc}
\hline & Top country of destination (as of 2016) & Number of students enrolled in HEIs \\
\hline China $^{\mathrm{a}}$ & $7628(43 \%)$ \\
South Korea $^{\mathrm{b}}$ & $2259(12.7 \%)$ \\
Japan $^{\mathrm{c}}$ & $1711(9 \%)$ \\
Russia $^{\mathrm{b}}$ & $1654(9 \%)$ \\
USA $^{\mathrm{b}}$ & $1425(8 \%)$ \\
\hline
\end{tabular}

${ }^{a}$ CSIS, 2018 (Data from China's Foreign Affairs) ${ }^{28}$

bUIS, $2018^{29}$

'JASSO, $2017^{30}$

The government of Mongolia promotes study abroad programs with the aim to prepare domestic students for international careers and develop future high-level human resources. In 2014, the government commenced the Higher Engineering Education Development Project in cooperation with the Japan International Cooperation Agency to train 1,000 Mongolian engineering students in Japan by 2023. Currently, 400 students, faculty members, and researchers have received the scholarship. ${ }^{31}$ In 1997-2017, 2076 students received Mongolian government and intergovernmental scholarships.

\section{International partnership and collaboration}

For HEIs worldwide, building relationships with counterparts abroad is seen as a key aspect of strategies for internationalization. A great number of HEIs around the world are eager to establish joint and dual degree programs and other types of partnerships with foreign institutions (especially in highly developed countries). With regard to internationalization abroad, Mongolian HEIs experience international partnership and collaboration in two ways: 1) joint/dual degree programs and student exchanges and 2) research and academic collaboration. Interestingly, the majority of joint/dual degree programs and exchanges are conducted in English with foreign partner universities in Asia, especially Japan, South Korea, China, and Taiwan weigh higher than in other regions. This trend is also observed in the online survey of this study (see more in detail from the online survey section). Examples of international collaboration show that 146 of 220 foreign partners with National University of Mongolia are from Asia, 83 of 137 at Mongolian University of Science and Technology, 47 of 70 at National University of Education and the list goes on (Figure 1). Student exchange programs are funded by an array of institutions, from private companies (e.g. Mitsubishi Scholarship) and national institutions (e.g. Mongolia-Namyangju Education Promotion Scholarship) to the government (e.g. Erasmus Mundus program).

Dual degree programs have become attractive for students interested in getting an international degree but have limited resources to complete full four years abroad. Thus, institutions offer such programs to attract more students and which require increased English language exposure, training, and quality in order to prepare students for partner institutions.

Research and academic collaboration is an excellent way to not only accelerate the internationalization process

student-flow-viz.aspx.

${ }^{27}$ Ministry of Education, Culture, Sciences, and Sports. (2018). Statistical Report of Higher Education Sector: 2017-2018 academic year. https:// mecss.gov.mn/news/728/

${ }^{28}$ CSIS-China power, 2018.

${ }^{29}$ UNESCO Institute for Statistics, 2018.

30 JASSO. (2017). Trend of Mongolians students in Japan (2004-2017). Unpublished data.

31 Munkhtulga, B. (2018, November 15). Our students will be coming as specialized engineers equipped with excellent Japanese and English, Daily News, 227, Ulaanbaatar. 


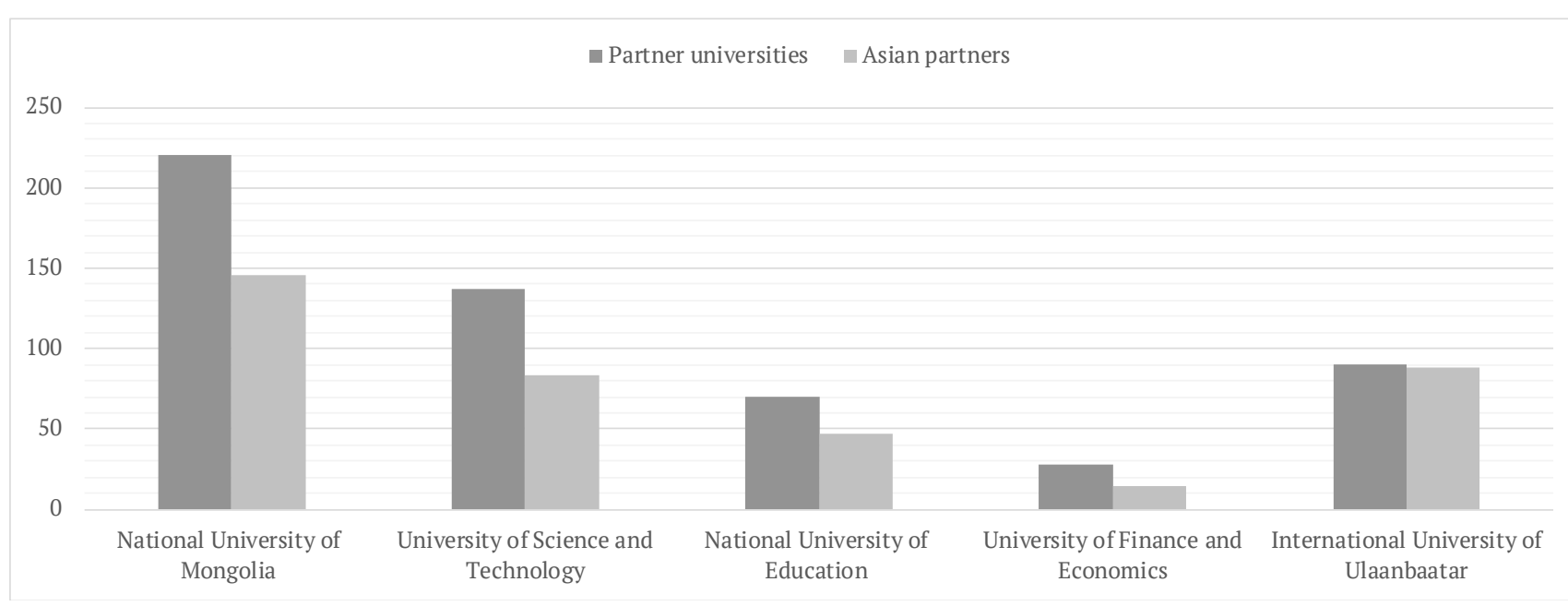

Figure 1. Cooperation with international partner universities.

but also enhance the institutional quality and improve the performance of partners. HEIs in Mongolia benefit from participating in effective research and academic collaborations with others, both within and outside the country. In 1974-2016, the government of Mongolia funded 4235 research projects (23.5\% in natural science, $23.5 \%$ in technology, $22.8 \%$ in medical science, $17.8 \%$ in social science, and $12.4 \%$ in agricultural science). ${ }^{32}$ However, joint projects make up a small percentage - $18 \%$ in the social sciences, $12 \%$ in natural sciences, $2 \%$ in medical science, $2 \%$ in the agriculture, and $2 \%$ in technology. In 2016, $\$ 3.1$ million was allotted to HEIs for 164 research projects (MFST, 2016). Unfortunately, Mongolian HEIs have not yet released any accurate data regarding their academic collaboration with foreign institutions.

\section{Survey results}

This section reports the findings from the survey. The main aim of the survey is to analyze the rationales for EMI and its practice in two private universities and to investigate how the faculty members understand the rationales. This survey involves two institutions that have started offering EMI courses earlier, in a more extensive way, and implementing it more aggressively than other Mongolian universities (see Table 5).

Table 5

Profile of the universities

\begin{tabular}{lcc}
\hline \multicolumn{1}{c}{ Basic information } & University A & University B \\
\hline Type of institution & Private & Private \\
Location & Ulaanbaatar & Ulaanbaatar \\
Approx. \# of undergraduate students & 4000 & 1000 \\
Approx. total \# of international undergraduate students & 70 & 150 \\
\# of undergraduate EMI & 12 (programs) & 13 (programs) \\
\hline
\end{tabular}

Note: data are from the universities' websites

To interpret the survey results, I explored documents related to EMI courses and programs, including materials from each university's websites and brochures. The results of the survey are presented below focusing on the questions about faculty member's understandings of the internal and external factors for implementing EMI at their university, challenges that they encounter while teaching EMI courses, and as well as their recommendations and suggestions for the improvement and efficacy of EMI programs and courses.

\section{What are the internal and external factors for implementing EMI programs?}

This section explored the internal and external factors for implementing EMI programs at the two universities (see Table 6). The respondents were asked to rank the three most important internal and external factors that encouraged their university to implement EMI. In regards to internal factors, the majority of the respondents

\footnotetext{
${ }^{32}$ Mongolian Foundation for Science and Technology. (2016). The 2016 Year Report. Retrieved from http://www.stf.mn/
} 
perceived that EMI programs were offered in order to improve their students' English proficiency and to prepare global citizens. This idea is connected to the notion of preparing global leaders who can be actively engaged in international activities through English. Faculties at University A ranked 'Increase the ranking of the university' as one of the main factors driving EMI policy while University B chose "Create an international environment for the students'.

Table 6 - Comparison of internal and external factors

\begin{tabular}{lll}
\hline & \multicolumn{1}{c}{ University A } & \multicolumn{1}{c}{ University B } \\
\hline \multirow{2}{*}{ Internal Factors } & Improve English skills of domestic students $(20)^{*}$ & Improve English skills of domestic students $(20)^{*}$ \\
& Prepare global citizens $(18)^{*}$ & Create an international environment for students (20)* \\
& Increase the ranking of the university $(18)^{*}$ & Prepare global citizens (20)* \\
\hline \multirow{2}{*}{ External Factors } & Student exchange programs $(20)^{*}$ & Student exchange programs $(20)^{*}$ \\
& International collaborations $(20)^{*}$ & International collaborations $(20)^{*}$ \\
& Domestic university ranking $(18)^{*}$ & Domestic university ranking $(20)^{*}$ \\
\hline
\end{tabular}

Note: (" number of faculty members who chose this response)

As for external factors, all respondents from both University A and University B believe that student exchange programs and international collaborations are the primary reasons for their universities to implement EMI programs. This pattern confirms the result of the document analysis that University A is actively engaged in international collaboration with foreign partner universities through various exchange degree programs. For University B, it seems the student exchange programs and international collaboration also play a crucial role in the implementation of EMI. In Mongolia, most of the student exchange programs in HEIs are run in English, hence EMI is seen as one of the external factors in the development of student exchange programs at these universities through international collaboration. Interestingly, the answers of the respondents of the two universities display that their universities place much emphasis on English education to raise their domestic university ranking, which is the third factor for implementing EMI.

\section{Challenges}

It is clear that there are many challenges that hinder the successful implementation of EMI. To gain a better understanding of these challenges, respondents were asked to choose the four most important challenges from the following key challenges.

- Student dissatisfaction

- Limited English proficiency of students

- Outside pressure

- Structural challenge

- Cultural challenge

- Increase in workload

- Linguistic difficulties

- Intercultural problems

Table 7 presents the list of challenges by the level of importance as determined by the number of respondents who ranked the challenges.

Table 7 - Comparison of challenges

\begin{tabular}{ll}
\hline \multicolumn{1}{c}{ University A } & \multicolumn{1}{c}{ University B } \\
\hline Increase in workload $(16)^{*}$ & Linguistic difficulties (14)* \\
Outside pressure (16)* & Structural challenge (14)** \\
Structural challenge (14)* & Cultural challenge $(14)^{*}$ \\
Linguistic difficulties $(14)^{*}$ & Limited English proficiency of students $(14)^{*}$ \\
\hline
\end{tabular}

Note: ("number of respondents) 
Table 7 illustrates that faculty members face difficulties in linguistics, culture-related issues, and structural problems. The linguistic difficulties include limitations in both professors' and students' English language proficiency, unfamiliar words, vocabularies and terminologies. Culture-related issues present challenges for educators accustomed to teaching a relatively homogeneous body of students as they may lack the intercultural knowledge and competencies as the introduction of EMI opens itself up to diverse student and teacher populations which differ in terms of academic cultural norms and expectations. Structural problems are those challenges related to the administration and management of the EMI program. For example, one such challenge involves language assessment policies for students and recruitment of local faculty members to teach EMI courses.

\section{Recommendations and Suggestions}

The survey had two open-ended questions and the purpose was to find out more about faculty members' experiences in EMI followed by a request to give their recommendations for those who are going to teach EMI courses and universities that are planning to offer EMI programs or courses. The answers showed that University A's faculty members focused more on the preparation of classes, pedagogical training for faculty members, and language issues while University B's faculty members gave more emphasis on collaborative ties between departments, and practical advice on what changes and challenges to expect.

In terms of recommendations for universities, University A's faculty members advised that a university planning to offer EMI programs or courses should provide their teachers with pedagogical training, course materials, and a good working environment. University B's faculty members recommended pedagogical training for faculty members, preparation of quality curriculums, and emphasis on English language proficiency of prospective students. It seems that pedagogical training or a workshop is important to the faculty members in order to work successfully in the EMI context and as well as the curricula along with course materials.

\section{Discussion and Conclusion}

This study attempted to explore the IoHE in Mongolia, current strategies and approaches to internationalization at the national and institutional levels, the concept of EMI policy and its implementation in Mongolian higher education context. Two research questions were raised:

1. What are the factors driving Mongolian higher education to pursue internationalization and English Medium Instruction?

2. How do the faculty members understand these rationales?

In terms of the first question, the document analysis illustrates that in a bigger picture, the world university rankings cause the government to push its national universities to pursue internationalization. The Mongolian government perceives the IoHE as a way to integrate international dimensions into higher education (Knight, 2003) in order to improve the quality of higher education (Soderqvist, 2002). It seems that academic rationales are more observed in the Mongolian higher education context. As Knight (2004) noted, academic rationales focus on the integration of an international dimension into research, teaching and academic standards, institution building, and enhancement of the institution's profile, status, and quality. According to Qiang (2003), there is an assumption that integrating the international dimension into teaching, research, and service enhances the quality of a higher education system. The notion of enhancing the quality of education is linked to the idea that internationalization serves as a positive change for institutional building.

Hazelkorn (2007) concludes from her study that world-ranking systems influenced key policymaking areas, e.g. the link between the classification of institutions and the allocation of funding. Indeed, the government of Mongolia has already classified the national universities as research-based or teaching-based universities. In her speech, Tsogzolmaa, the Minister of Education, ${ }^{33}$ put great emphasis on rendering all types of support including financial support to one of the top national universities in order to enable them to compete in Asian ranking systems.

33 Tsogzolmaa, Ts. (2017, December 5). We highly focus on the status of the National University of Mongolia. Montsame. Retrieved from https://montsame.mn/mn/read/74418 
At the institutional level, national universities put a greater emphasis on rankings, research output in journals with a high impact factor, international collaboration and delivery of courses in English. As expected in the Roadmap for Higher Education Reform 2010-2021, Mongolia's first ambitious priority is to have four universities to be internationally visible at least in Asia by $2021 .{ }^{34}$ However, the plan is way behind the schedule. None of the government policy documents clearly described which of the popular global university rankings the national universities should follow. The ranking systems are different in terms of their indicators. If Mongolia wants to make some of its top national universities to be visible at least in Asia, they will definitely need to increase the number of international students and international faculty members and research output, as well as international collaborations. The current position and status of national universities in Mongolia show that they are most likely to fail if they do not consider the above areas. As for private universities in Mongolia, they may compete with each other but not with national universities. The reason is that currently there is no comprehensive private university in Mongolia and most of the private universities are social and human sciences universities. In comparison to national universities, private institutions are increasingly applying for international accreditations to compete for high-tuition paying domestic students. Although the government of Mongolia has made progress through strategic actions and projects in the higher education sector, Mongolia's internationalization efforts are still dispersed and managed in an ad-hoc fashion. One of the main reasons is that higher education policies and laws are not stable and they constantly change. Consequently, the internationalization process is slowing.

Within the framework of the dimensions of internationalization, it is interesting to see in the first dimension of faculty development that the government of Mongolia and the national universities put more emphasis on developing the existing faculty members rather than recruiting international faculty. Both the government and national universities believe that increasing the number of faculties with $\mathrm{PhD}$ degrees (preferably in developed countries) would help to increase the universities' research output and international reputation. However, this raises two issues. First, currently, there is no national policy focusing on the development of the existing or new faculty members. Second, it is still not clear how stable government policy will be to support HEIs. In other words, the delay in the implementation of faculty development makes the progress in internationalization policy slow. More active and dedicated actions toward faculty development and incentives may lead to the growth in the proportion of top-tier journal papers. Thus, the Mongolian government should consider actions to intensify faculty development on a substantial scale for the development of scientific research in the country.

Internationalization of the curriculum is also an important dimension of internationalization in Mongolian higher education. As Leask (2015, p.9) defined, internationalization of curriculum is, "the incorporation of international, intercultural, and/or global dimensions into the content of the curriculum as well as the learning outcomes, assessment tasks, teaching methods, and support services of a program of study". Internationalization of curriculum requires a change at the program level in order to impact on the student experience and bring an intercultural experience into the classroom (Foster \& Anderson, 2015).

Internationalization of curriculum is divided into nine types of categories in "Typology for Internationalizing Curriculum” proposed by Bremer \& Van der Wende (1995). Accordingly, based on the document analysis, the internationalized curricula in Mongolian higher education context most often conformed to the types 1 (curricula with an international subject), 3 (curricula which prepare students for international professions), 4 (curricula in foreign languages or linguistics which explicitly address cross-communication issues and provide training in intercultural skills), 5 (interdisciplinary programs), 6 (curricula leading to internationally recognized professional qualifications), and 7 (curricula leading to joint or double degrees).

As for the third and fourth dimensions of internationalization, it is clear that private rather than national universities are more likely to utilize the forms of international delivery through joint and dual degree programs as Deschamps and Lee (2015) claimed. Joint and dual degree programs in Mongolia support domestic students to study abroad rather than to recruit international students. The medium of instruction in the courses offered in the joint and dual degree programs is mainly English. The country will remain disadvantaged if the number of programs in English is not leveraged. This is crucial to many aspects of internationalization. While many foreign institutions implement EMI to attract international students, this does not seem to be a practice at Mongolian HEIs. Most Mongolian universities have no intention to attract international students except very

\footnotetext{
${ }_{34}$ Ministry of Education, Culture, and Sciences. (2010). Roadmap for Higher Education Reform 2010-2021. Retrieved from http://www.mesc.gov. $\mathrm{mn} /$ article-398-435.mw
} 
few private universities. Universities tend to encourage domestic students to study abroad in order to prepare human resource who will be able to work in a diverse and competitive international market.

The Mongolian government is the key player in IoHE by making policies, taking initiatives, and encouraging national universities. However, the process of internationalization is much slower in private HEIs. More indepth research and particularly qualitative research of a comparative nature is clearly needed in order to gain greater insights into how the IoHE is implemented at national and institutional levels.

As Macaro et al. (2018) concluded, the rationales for adopting EMI in a broader global context include: 1) a perceived need to internationalize the university; 2 ) the need to attract foreign students due to the decreasing number of domestic students; 3) the need to financially sustain HEIs; 4) competition between national and private HEIs; and 5) the importance of English in academic research publications. In comparison, the online survey analysis identified that faculty members understand that their universities implement EMI for the following three reasons: 1) increasing the employability of domestic graduates in an international market; 2) promotion of international collaboration; and 3) improving domestic and international profile. These three reasons are interrelated. Private universities promote international collaboration via joint and dual degree EMI programs and pay greater attention to the employment ratio of their graduates due to the increasing demands of international and domestic business organizations to hire graduates who will be able to work internationally. English language knowledge is one of the main requirements for employment. As noted, this survey was conducted for the first time in the Mongolian context. Due to some limitations in this study, a more in-depth study including interviews with the faculty members and administrators of EMI programs should be conducted to have a more complete view of the EMI in Mongolia. In addition, a comparison of data from other private universities would have been valuable.

\section{References}

Agvaantseren, U., \& Hoon, P. (2013). Comparatives Korean and Mongolian achievement in higher education. International Journal of Sciences: Basic and Applied Research, 11, 49-55.

Altan-Od, D., \& Khongorzul, D. (2012). Some issues on English language education policy. In Ch. Zegiimaa (Ed), Language policy and language planning of Mongolia: Some issues on English language education policy (pp. 118120). Ulaanbaator, Mongolia: Bembi San.

Altbach, P. G., Reisberg, L., \& Rumbley, L. E. (2009). Trends in global higher education: Tracking an academic revolution. Paris, France: United Nations Educational, Scientific and Cultural Organization.

Bremer, L., \& Van Der Wende, M. (1995). Internationalizing the curriculum in higher education: Experiences in the Netherlands. Hague, Netherlands: The Netherlands Organization for International Cooperation in Higher Education.

Coffey, A., \& Atkinson, P. (1996). Making sense of qualitative data: Complementary research strategies. Thousand Oaks, CA: Sage.

Coleman, J. (2006). English-medium teaching in European higher education. Language Teaching, 39(01), 1-14. https://doi.org/10.1017/S026144480600320X

Dearden, J. (2014). English as a medium of instruction - A growing phenomenon. London, UK: British Council. Retrieved from: https://www.britishcouncil.org/sites/default/files/e484_emi_cover_option_3_final_web.pdf.

Deschamps, E., \& Lee, J. (2015). Internationalization as mergers and acquisitions: Senior international officers' entrepreneurial strategies and activities in public universities. Journal of Studies in International Education, 19(2), 122-139. https://doi.org/10.1177/1028315314538284.

De Wit, H. (2000). Changing rationales for the internationalization of higher education. Internationalization of Higher Education: An Institutional Perspective, 15, 2-3. https://doi.org/10.6017/ihe.1999.15.6477

Enkhtur, A. (2019). Government-sponsored students as agents of national development? Perspectives of Mongolian alumni from Japanese graduate schools (Unpublished doctoral dissertation). Osaka University, Osaka, Japan.

Fink, L. (2013). The Current status of faculty development internationally. International Journal for The Scholarship of Teaching And Learning, 7(2), 1-9. https://doi.org/10.20429/ijsotl.2013.070204.

Foster, M., \& Anderson, L. (Eds.) (2015). Exploring internationalization of the curriculum to enhance the student experience. Journal of Perspectives in Applied Academic Practice, 3(3), 1-2. https://doi.org/10.14297/ jpaap.v3i3.206. Retrieved from: http://jpaap.napier.ac.uk/index.php/JPAAP/article/view/206/html 
Gantsog, T., \& Altantsetseg, S. (2003). Globalization, WTO and Mongolian higher education. New York, NY: International Policy Fellowships.

Graddol, D. (1997). The future of English? A guide to forecasting the popularity of the English language in the 21st century. London, UK: The British Council.

Itgel, M., Oyungoo, B., Sumyasuren, T., \& Otgon-Erdene, X. (2018). Possibilities and ways to support higher education faculty development. Retrieved from http://zuvluguun.num.edu.mn/conf2018/Home/present/13

Jargalmaa, J. (2015). Internationalization of Mongolian higher education: With special reference to the Mongolian National University. Kyoto, Japan: Kyoto University Graduate School of Education.

Knight, J. (2003). Updated internationalization definition. International Higher Education, 33, 2-3. https://doi. org/10.6017/ihe.2003.33.7391

Knight, J. (2004). Internationalization remodeled: Definition, approaches, and rationales. Journal of Studies in International Education, 8(1), 5-31. https://doi.org/10.1177/1028315303260832

Knight, J., \& de Wit, H. (1997). Internationalization of higher education in Asia Pacific countries. Amsterdam, Netherlands: European Association for International Education.

Hazelkorn, E. (2007). The impact of league tables and ranking systems on higher education decision-making. Higher Education Management and Policy, 19(2), 87-110. https://doi.org/10.1787/hemp-v19-art12-en.

$\mathrm{Hu}, \mathrm{T}$. (2017). Advancing research and innovation with Web of Science. International Organization for Migration. Retrieved from https://news.num.edu.mn/wp-content/uploads/2017/11/WOS-Night_2017.pdf

Hudzik, J.K.(2015). Comprehensive internationalization:Institutional pathways to success. New York, NY: Routledge.

Leask, B. (2015). Internationalizing the Curriculum. Abingdon, UK: Routledge.

Loo, B. (2017). Mongolia: Higher education and mobility. International Higher Education, 89, 19-21. https://doi. org/10.6017/ihe.2017.89.9841

Macaro, E., Curle, S., Pun, J., An, J., \& Dearden, J. (2018). A systematic review of English medium instruction in higher education. Language Teaching, 51(1), 36-76. https://doi.org/10.1017/S0261444817000350

Narankhuu, L., \& Batkhishig, I. (2015). To the issues on Higher Education Faculty development. Retrieved from https://www.slideshare.net/ankhbilegluvsan/ss-47550077

Patton, M.Q. (2002). Qualitative research \& evaluation methods ( $3^{\text {rd }}$ ed.) London, UK: Sage Publications.

Patton, M. (1990). Qualitative evaluation and research methods (pp.169-186). Beverly Hills, CA: Sage.

Soderqvist, M. (2002). Internationalization and its management at higher-education institutions: Applying conceptual, content and discourse analysis. Helsinki, Finland: Helsinki School of Economics.

Sodnomtseren, A. (2015). The impact of globalization: A case of Mongolian Universities. International Higher Education, (43). https://doi.org/10.6017/ihe.2006.43.7899.

Stigger, E. (2018). Introduction: Internationalization in Higher Education. In E. Stigger, M. Wang, D. Laurence \& A. Bordilovskaya (Eds.), Internationalization within Higher Education: Perspectives from Japan (pp. 1-19). Singapore, the Republic of Singapore: Springer Singapore. https://doi.org/10.1007/978-981-10-8255-9_1.

Yonezawa, A., \& Shimmi, Y. (2015). Transformation of university governance through internationalization: Challenges for top universities and government policies in Japan. Higher Education, 70(2), 173-186. https:// doi.org/10.1007/978-94-6300-773-3_6. 


\section{Appendix 1}

\section{Online questionnaire}

Thank you for your consideration to take part in this study. This survey is for teachers who teach courses in English or those who are part of programs that offer courses in English. The purposes of this survey are to explore the English Medium Instruction (EMI) policy at the institutional level, analyze the EMI practices in higher education institutions, and investigate factors that influence the decision-making and adoption of EMI policy at the institutional level. This study is part of doctoral thesis research of Mr Gundsambuu SAINBAYAR at Graduate School of Human Sciences, Osaka University.

This survey will take about 10-15 minutes to fill out. Your response to this survey will be anonymous and all personal information will be confidential. If you agree to participate in this study, please complete the following survey. Should you have any questions, please contact Mr Sainbayar at sgundsam@fulbrightmail.org. This study uses the definition of EMI by Oxford Center as, "The use of the English language to teach academic subjects in countries or jurisdictions where the first language of the majority of the population is not English."

I. Personal information (* Required)

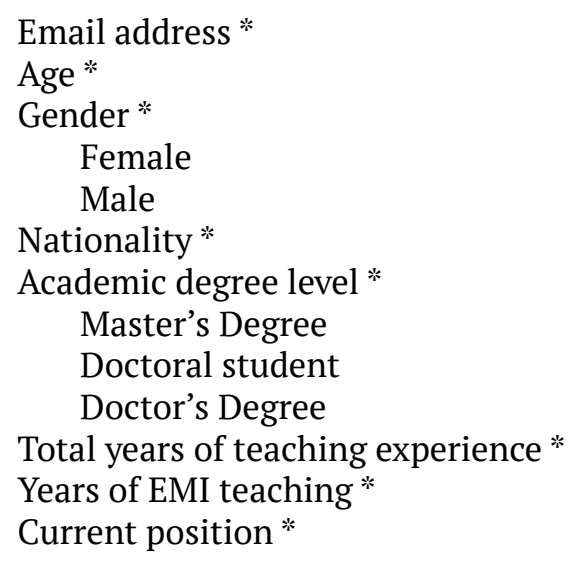

II. Survey questions

1. What courses do you teach in English? (Please write the course names)

2. Do you teach in the local language, too?
o Yes

o No

3. How many EMI courses do you teach per year?*

4. How long have you been teaching at the current university? *

5 . What level of students do you teach? * (Select only one that applies)

o undergraduate students

o graduate students

o both

o Other:

6. How do you see the objectives for implementing EMI courses at your university? * (Select only one per row)

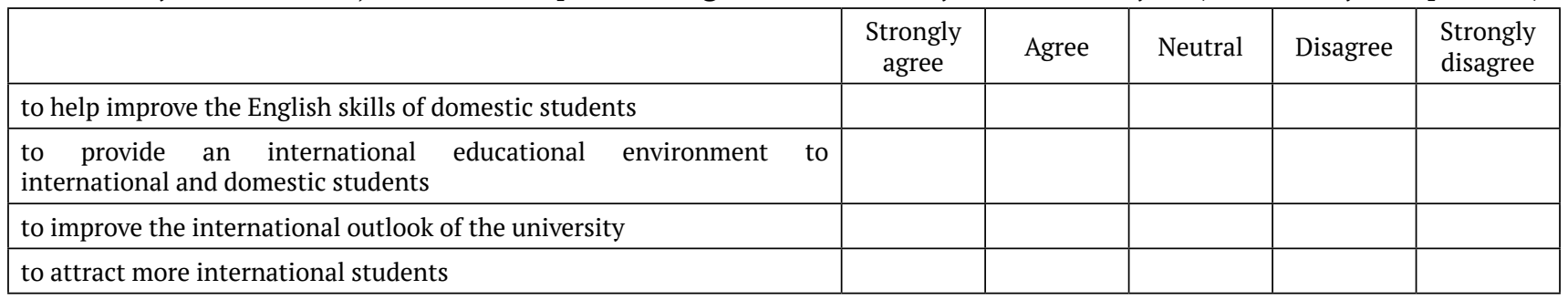




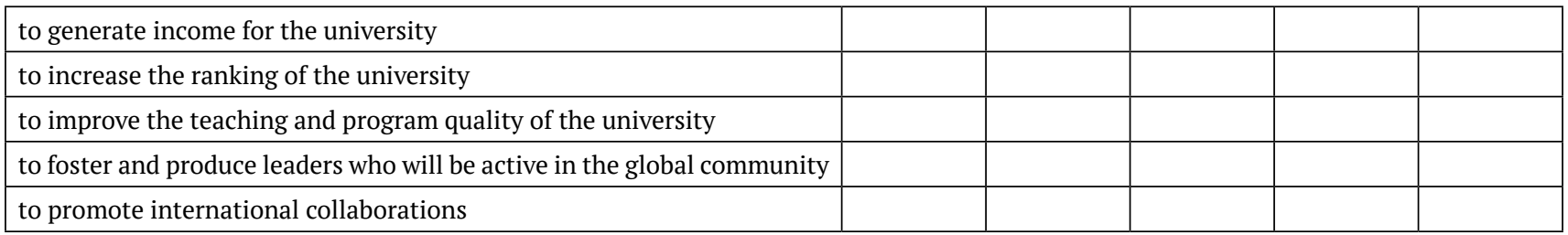

7. Have you ever been involved in any of the decision-making processes of adoption of EMI at your university? *

o Yes (If "yes", please go to question No. 8)

o No (If "no", please go to question No. 9)

8. What level have you been involved? Please check all possible answers. * (Select all that apply)

o Decision-making committee

o Administration

o Institutional policy plan to adopt EMI

o Research on EMI policy

o Curriculum design

o Program design

o Fundraising

o Other:

9. What do you think are the reasons/factors that influenced your university to adopt EMI? * (Select only one per row)

\begin{tabular}{|c|c|c|c|c|c|}
\hline & $\begin{array}{c}\text { Strongly } \\
\text { agree }\end{array}$ & Agree & Neutral & Disagree & $\begin{array}{l}\text { Strongly } \\
\text { disagree }\end{array}$ \\
\hline \multicolumn{6}{|l|}{ domestic university rankings } \\
\hline \multicolumn{6}{|l|}{ global university rankings } \\
\hline \multicolumn{6}{|l|}{ the decrease in enrollment of domestic students } \\
\hline \multicolumn{6}{|l|}{ funding from the government } \\
\hline \multicolumn{6}{|l|}{ international collaboration } \\
\hline \multicolumn{6}{|l|}{ student exchange programs } \\
\hline \multicolumn{6}{|l|}{ preparation of globally competitive graduates } \\
\hline increase in national economic competitiveness & & & & & \\
\hline
\end{tabular}

10. What are the expected outcomes of the implementation of EMI at your university? * (Select only one per row)

\begin{tabular}{|c|c|c|c|c|c|}
\hline & $\begin{array}{l}\text { Strongly } \\
\text { agree }\end{array}$ & Agree & Neutral & Disagree & $\begin{array}{l}\text { Strongly } \\
\text { disagree }\end{array}$ \\
\hline \multicolumn{6}{|l|}{ increase in domestic rankings } \\
\hline \multicolumn{6}{|c|}{ increase in international rankings } \\
\hline \multicolumn{6}{|l|}{ more financial support } \\
\hline \multicolumn{6}{|l|}{ highly skilled domestic students } \\
\hline \multicolumn{6}{|c|}{ more internationalized domestic students } \\
\hline \multicolumn{6}{|c|}{ more internationalized university } \\
\hline student employment results & & & & & \\
\hline
\end{tabular}

11. What do you think is the progress of EMI implementation at your university? * (Select only one)

\begin{tabular}{|l|l|l|l|l|l|l|}
\hline & 1 & 2 & 3 & 4 & 5 & \\
\hline Poor & & & & & & Excellent \\
\hline
\end{tabular}

12. What challenges associated with the EMI have you experienced? * (Select only one per row)

\begin{tabular}{|l|c|c|c|c|c|}
\hline & $\begin{array}{c}\text { Strongly } \\
\text { agree }\end{array}$ & Agree & Neutral & $\begin{array}{c}\text { Disagree } \\
\text { Strongly } \\
\text { disagree }\end{array}$ \\
\hline intercultural problems & & & & & \\
\hline linguistic difficulties & & & & & \\
\hline
\end{tabular}




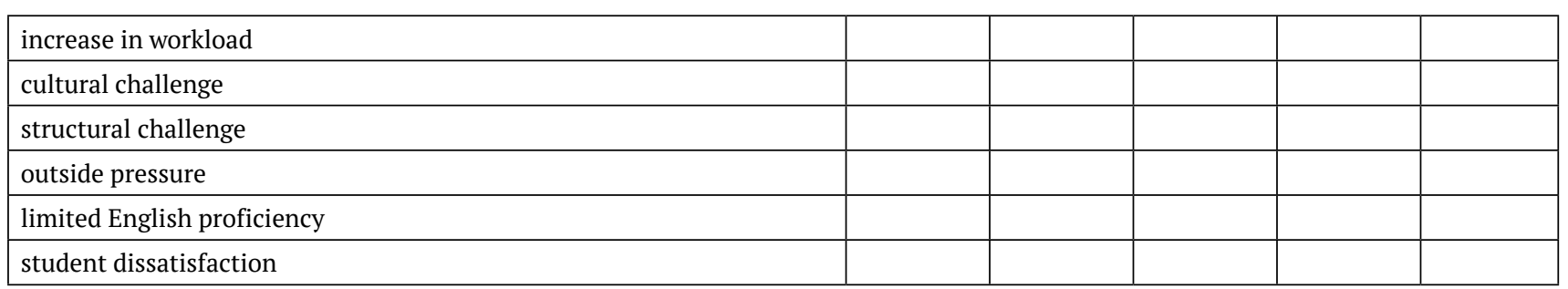

13. How have you overcome obstacles in the EMI courses? * (Select all that apply)

o support from the university

o teach in a mix of languages

o group students based on ability

o lowered the assessment criteria of course assignments

o discussion with students to identify their weaknesses and anxiety issues

$o$ attend an intensive support course focused on linguistic and pedagogic issues

o shape the teaching context to suit students' needs

o Other:

14. Have you been provided with any type of training or support to help you work successfully in the EMI courses or programs?*

o Yes (If "yes", please go to question No. 15.)

o No (If "no", please go to question No. 16.)

15. Please check what type of training or support you were provided. * (Select all that apply)

o language

o intercultural communication

o pedagogical

o assessment

o financial support

o Other:

16. If extra-training or support were to be offered, what type of training or support would you like to receive? * (Select all that apply)
o language
o intercultural communication
o pedagogical
o assessment
o financial support
o educational materials
o Other:

17. What advice would you give to teachers who are going to work on an EMI course or program?*

18. What advice would you give to a university, which is going to introduce or implement EMI? *

Thank you very much for completing this survey.

I would like to invite you to participate in a follow-up interview to elaborate on your opinion regarding your experience in teaching EMI courses in Mongolia. The interview will last for 40 minutes to 1 hour. Are you willing to participate in the interview?
o Yes
o No

Thank you very much for taking part in the study. 